\title{
Grain productive efficiency of soybean plants under lactofen application
}

\author{
Willian Pelisser da Rosa, Andréia Caverzan \& Geraldo Chavarria* \\ Faculty of Agronomy and Veterinary Medicine, Agronomy Post-Graduate Program, University of Passo Fundo, Passo Fundo/RS, 99052-900, Brazil \\ *Email: geraldochavarria@upf.br
}

\section{ARTICLE HISTORY}

Received: 22 January 2020

Accepted: 13 April 2020

Published: 16 May 2020

\section{ABSTRACT}

Adverse factors cause a decrease in the productive potential of crops. For soybean [(Glycine max (L.) Merrill], the excessive growth is a factor that results in plants with low effective efficiency. Thus, plants with an architecture that favours greater interception of solar radiation and deposition of pesticides tend to be more productive. The objective of this study is to evaluate the different application of lactofen, which is used as a growth inhibitor, improve the productive efficiency of soybeans by increasing the biological activity of the leaves. The study was conducted in the field with soybean cultivars NA 5909 RG and BMX Potência RR. The experiment followed a randomized complete block design with four treatments and five replicates: $\mathrm{T}_{1}$ : control; $\mathrm{T}_{2}$ : application of $140 \mathrm{~g}$ a.i ha ${ }^{-1}$ of lactofen in phenological stage $\mathrm{V}_{3} ; \mathrm{T}_{3}$ : application of $140 \mathrm{~g}$ a.i ha ${ }^{-1}$ of lactofen in phenological stage $\mathrm{V}_{6}$; and $\mathrm{T}_{4}$ : application of $70 \mathrm{~g}$ a.i ha ${ }^{-1}$ of lactofen in phenological stage $V_{3}+70 \mathrm{~g}$ a.i ha ${ }^{-1}$ of lactofen in phenological stage $\mathrm{V}_{6}$. The interception of photosynthetically active radiation in the lower layer increased in all treatments. Lactofen application increased the percent area covered and the number of phytosanitary products spray droplets per $\mathrm{cm}^{2}$ in the middle and lower layers of the plants. The lower third of the plants experienced the greatest effect of the treatments with regard to the number of pods, grains and grain weight, with treatment $\mathrm{T}_{2}$ presenting significant increases. The use of lactofen as a growth inhibitor at the beginning of pod development in soybean caused changes to plant architecture and root development, consequently enhanced the productive efficiency of the plant, primarily due to increased grain production in the lower layer. Future research using lactofen in different phenological stages and cultivars may provide more insights in to the performance of this growth inhibitor in soybean.

\section{Introduction}

The main oilseed produced in the world is the soybean [Glycine max (L.) Merrill], providing source of protein to the animal feed and also in human diet (1). A number of adverse factors like biotic and abiotic stress, environmental adversities, genetic potential, physiological condition, and others cause a decrease in the productive capacity of soybean plants, including excessive growth, which results in plants with low productive efficiency (2). This reduction in grain productive efficiency is primarily caused by low photosynthetic activity, which itself is mainly related to canopy-shading, especially in the lower layer of the plants. Canopy cover causes the leaves in the lower layer not to receive sufficient light for their maintenance. These leaves enter in senescence and fall, consequently, the nodes in this layer are incapable of producing pod and grains (3). In addition, to yield loss due to canopy-shading, it is difficult to control diseases and pests due to the difficulty of pesticides reaching all the leaves during the spraying (4).

Growth inhibitors are natural or synthetic chemicals that may alter vital or structural processes of plants by modifying hormone balance (5), reducing plant height without affecting environmental and morphological standards (6). Therefore, management techniques like as the use of growth inhibitors in different concentrations and growth stages have been studied for the cultivation of wheat (7), barley (5), sugarcane (8) and cotton (9). For soybean, the doses vary of the $70 \mathrm{~g}$ a.i. ha ${ }^{-1}(10)$, to $240 \mathrm{~g}$ a.i. $\mathrm{ha}^{-1}(11,12)$

\footnotetext{
(c) Rosa et. al (2020). This is an open-access article distributed under the terms of the Creative Commons Attribution License, which permits unrestricted use,
} distribution and reproduction in any medium, provided the original author and source are credited (https://creativecommons.org/licenses/by/4.0/). 
applied in different stages. However, studies on soybean are still needed for a deeper understanding of solar radiation interception and pesticide deposition on leaves.

The growth inhibitor lactofen causes phytotoxicity in the plants after its application, inhibiting plant growth, breaking the apical dominance and inducing the growth of lateral branches so that the plants tend to be dwarf (11). Therefore, this study tested the hypothesis that the use of lactofen on tall cultivars with indeterminate growth habits would tend to improve their productive characteristics, leading to more efficient photosynthetic activity and facilitating pesticide spraying for disease control. These effects would thereby increase grain yield, especially in the lower layer of the plant. The objective of this study is to evaluate the different treatment application of lactofen, which is used as a growth inhibitor, improve the productive efficiency of soybeans by increasing the biological activity of the leaves.

\section{Materials and Methods}

\section{Study focus}

The study was conducted in the field during the 201516 production season (November-March) at the Municipality of Passo Fundo, Rio Grande do Sul state (RS), Brazil at $28^{\circ} 23^{\prime} \mathrm{S}, 52^{\circ} 38^{\prime} \mathrm{W}$ at an altitude of 687 meters. Two experiments were performed, each with a different soybean released varieties: (i) BMX Potência RR (BRASMAX Genética), which is tall, has indeterminate growth habits, semi-early maturation (group 6.7, 140 days), and is high-branching; and (ii) NA 5909 RG (NIDERA Sementes), which is tall, has indeterminate growth habits, early maturation (group 5.9, 130-140 days), and is high-branching. The growth inhibitor used was lactofen $\left(\mathrm{C}_{19} \mathrm{H}_{15} \mathrm{ClF}_{3} \mathrm{NO}_{7}\right)$ at a concentration of $240 \mathrm{~g}$ a.i $\mathrm{L}^{-1}$, which is a diphenyl ether herbicide recommended to control broadleaved weeds (13). The lactofen mechanism action is the inhibition protoporphyrinogen-IX oxidase (Protox enzyme), that acts in chlorophyll biosynthesis.

\section{Experimental design}

The experiments were conducted in a randomized complete block design consisting of four treatments and five replicates: $\mathrm{T}_{1}$ : control; $\mathrm{T}_{2}$ : application of $140 \mathrm{~g}$ a.i ha ${ }^{-1}$ of lactofen in stage $\mathrm{V}_{3} ; \mathrm{T}_{3}$ : application of $140 \mathrm{~g}$ a.i ha ${ }^{-1}$ of lactofen in stage $\mathrm{V}_{6}$; and $\mathrm{T}_{4}$ : application of 70 $\mathrm{g}$ a.i ha ${ }^{-1}$ of lactofen in stage $\mathrm{V}_{3}+70 \mathrm{~g}$ a.i ha ${ }^{-1}$ of lactofen in stage $V_{6}$, according to the phenological scale proposed by Fehr et al. (14). The fertilization was carried out with $6 \mathrm{~kg} \cdot \mathrm{ha}^{-1}$ of $\mathrm{N}, 60 \mathrm{~kg}$.ha-1 of $\mathrm{P}_{2} \mathrm{O}_{5}$ and $60 \mathrm{~kg} \mathrm{ha}^{-1}$ of $\mathrm{K}_{2} \mathrm{O}$. The seeds were inoculated with Bradyrhizobium japonicum and treated with insecticides (imidacloprid and thiodicarb) and fungicides (carbendazim and thiram). Proper plant density was 25 plants $\mathrm{m}^{-2}$ and 28 plants $\mathrm{m}^{-2}$ for BMX Potência RR (BRASMAX Genética) and NA 5909 RG (NIDERA Sementes), respectively. Each experimental plot was composed of seven $9 \mathrm{~m}$ long planting rows spaced $0.45 \mathrm{~m}$ apart. Lactofen was applied with a $\mathrm{CO}_{2}$-pressurized backpack sprayer (Herbicat, HB PES 003) fitted with a spray boom containing four turbos flat TeeJet ${ }^{\circledR}$ TT110015 spray nozzles, which produced medium-sized droplets (15). The nozzles were spaced $0.50 \mathrm{~m}$ apart, with constant working pressure, set to a spray volume of $150 \mathrm{~L} \mathrm{ha}^{-1}$.

\section{Nodulation and root characterization}

The nodulation was evaluated at phenological stage $\mathrm{V}_{3}$ and $\mathrm{V}_{6}$. Ten plants per plot were collected. The number of nodules were counted and the nodules were taken to a drying oven $\left(60^{\circ} \mathrm{C}\right)$ for reached constant mass (16). After drying, the nodule dry mass per plant (g) was determined. To evaluate the roots, samples were collected at phenological stage R5.1. The samples were collected as soil blocks of known area, according to the method proposed by Böhm (17). The blocks measured $0.3 \mathrm{~m}$ in depth $\mathrm{x} 0.45 \mathrm{~m}$ length $\mathrm{x} 0.45 \mathrm{~m}$ width. The roots were washed for soil removal using metal tables with metal screens. The evaluations of the volume $\left(\mathrm{cm}^{3} \mathrm{~m}^{-2}\right)$, specific surface area $\left(\mathrm{cm}^{2} \mathrm{~m}^{-2}\right)$, dry mass $\left(\mathrm{g} \mathrm{m}^{-2}\right)$ and length $(\mathrm{cm})$ were performed. The results were extrapolated to $1 \mathrm{~m}^{2}$ of soil at the collection depth of $0.3 \mathrm{~m}$. The volume and specific surface area were determined using an image analysis method with the Fibre and Root Analysis System (SAFIRA). The root dry mass was obtained by drying in an oven at $60{ }^{\circ} \mathrm{C}$ to a constant weight. The root lengths were obtained by a simple measurement of the taproot with a ruler.

\section{Characterization of photosynthetically active radiation interception}

The interception of photosynthetically active radiation in the upper and lower strata of the plant canopy and the light extinction coefficient (k) were monitored beginning at phenological stage R1. The solar radiation intercepted in the upper and lower layers was determined as follows: the total radiation intercepted in the upper layer minus that intercepted in the middle layer provides values for the upper layer, and this value minus the interception in the lower layer provides the value for the lower layer. These readings were performed with the aid of a ceptometer (AccuPAR, LP-80), which was positioned in the inter-row at the different layers. The readings were performed over 10 days, always at noon and on days with a completely clear sky (18). The results were expressed in $\mu \mathrm{mol} . \mathrm{m}^{-2} \mathrm{~s}^{-1}$.

\section{Characterization of droplet deposition}

For the evaluation of droplet deposition, spray application was performed only with water using a mechanized sprayer (Jacto, CONDOR 600 M12), equipped with TeeJet ${ }^{\circledR}$ TT110015 turbo flat spray nozzles, which produced medium-sized droplets (15). The working speed was set at $6.0 \mathrm{~km} \mathrm{~h}^{-1}$ to obtain a spray volume of $150 \mathrm{~L} \mathrm{ha}^{-1}$. At the time of spraying for each of the treatments (stage R2), water-sensitive paper (SYN7626) was placed in each third of the plants (upper, middle and lower), attached by an iron rod inserted into the ground in the inter-row. The purpose of this study is to evaluate the deposition of pesticide spray on the different layers of the plant. After application, the papers were labelled and stored in paper envelopes to determine the percent area covered and the number of droplets per $\mathrm{cm}^{2}$. Reading of the papers was performed using the DropScope ${ }^{\circledR}$ program. 


\section{Grain yield components}

Ten plants of each plot were randomly selected. The variables related to the yield components were estimated and stratified by plant layer (upper, middle and lower) as follows: number of pods per layer, total pods per plant, number of empty pods per layer, total empty pods per plant, number of grains, and grain weight per layer (corrected for 13\% moisture). For the determination of grain yield $\left(\mathrm{kg} \mathrm{ha}^{-1}\right)$, the harvest was carried out with a plot harvester (SEMINA, M1400). The samples were weighed, corrected to $13 \%$ moisture and processed to obtain the grain yield per hectare. The thousand-grain weight (TGW) was determined at the time of harvest by collecting one sample and counting 250 grains, with the correction to $13 \%$ moisture.

\section{Statistical analysis}

The data were subjected to analysis of variance (ANOVA), and the means were compared using Duncan's test at $5 \%$ probability. The statistical program CoStat ${ }^{\circledR}(19)$ was used.

\section{Results and Discussion}

The application of lactofen at the distinct phenological stages and doses did not alter the number and dry mass of nodules for the cultivar NA 5909 RG. The treatments did not affect the number of nodules of the cultivar BMX Potência RR (Table 1).

Table 1. Number and dry mass of nodules for soybean cultivars subjected to lactofen application

\begin{tabular}{|c|c|c|c|c|}
\hline \multicolumn{5}{|c|}{ NA 5909 RG } \\
\hline \multirow{2}{*}{ Treatment } & \multicolumn{2}{|c|}{ V3 stage } & \multicolumn{2}{|c|}{ V6 stage } \\
\hline & Nodules & Dry mass (g) & Nodules & Dry mass (g) \\
\hline $\mathrm{T}_{1}$ & $29.2^{\mathrm{ns}^{*}}$ & $0.1^{\mathrm{ns}}$ & $55.8^{\text {ns }}$ & $0.3^{\mathrm{ns}}$ \\
\hline $\mathrm{T}_{2}$ & 30.8 & 0.1 & 53.9 & 0.3 \\
\hline $\mathrm{T}_{3}$ & 30.4 & 0.1 & 62.0 & 0.2 \\
\hline $\mathrm{T}_{4}$ & 28.1 & 0.1 & 63.1 & 0.3 \\
\hline Significance & 0,8216 & 0,5102 & 0,1598 & 0,7082 \\
\hline CV (\%) & 12.6 & 14.8 & 11.1 & 12.3 \\
\hline \multicolumn{5}{|c|}{ BMX Potência RR } \\
\hline \multirow{2}{*}{ Treatment } & \multicolumn{2}{|c|}{ V3 stage } & \multicolumn{2}{|c|}{ V6 stage } \\
\hline & Nodules & Dry mass (g) & Nodules & Dry mass (g) \\
\hline $\mathrm{T} 1$ & $23.4^{\mathrm{ns}^{*}}$ & $0.1^{\mathrm{ns}}$ & $80.6^{\text {ns }}$ & $0.3 \mathrm{a}$ \\
\hline $\mathrm{T} 2$ & 24.3 & 0.1 & 61.5 & $0.2 \mathrm{c}$ \\
\hline T3 & 24.9 & 0.1 & 80.7 & $0.3 \mathrm{ab}$ \\
\hline $\mathrm{T} 4$ & 25.5 & 0.1 & 63.8 & $0.3 \mathrm{bc}$ \\
\hline C.V. (\%) & 8.1 & 14.2 & 21.9 & 14.8 \\
\hline Significance & 0,4772 & 0,7143 & 0,3366 & 0,0157 \\
\hline
\end{tabular}

Means followed by lowercase letters in the same column do not differ at a $\mathrm{p}>0,05$ by the Duncan test. ns: Non-significant. C.V.: Coefficient of variation. V3 - third trefoil open, without the leaflet margins touching. V6 - sixth trefoil open, without the leaflet margins touching. Treatments: T1- control 0; $\mathrm{T} 2-140 \mathrm{~g}$ a.i ha ${ }^{-1}$ at phenological stage V3; T3 $140 \mathrm{~g}^{\mathrm{a} . \mathrm{i}} \mathrm{ha}^{-1}$ at phenological stage V6; T4 $70 \mathrm{~g}$ a.i ha ${ }^{-1}$ at phenological stage $\mathrm{V} 3+70 \mathrm{~g} \mathrm{a.i} \mathrm{ha}^{-1}$ at phenological stage V6. * - means per plant.

The dry mass of the nodules in the phenological stage $\mathrm{V}_{3}$ did not differ among the treatments, while phenological stage $\mathrm{V}_{6}$ showed a difference among the treatments (Table 1). Specifically, application of $140 \mathrm{~g}$ a.i ha ${ }^{-1}$ of lactofen in phenological stage $V_{3}$ (treatment 2) resulted in a nodule dry mass of $0.23 \mathrm{~g}$, which was the lowest value, whereas this value for the control condition was $0.33 \mathrm{~g}$, the highest observed value (Table 1).

For good biological nitrogen fixation (BNF), it is necessary to have between 15 and 30 nodules per plant with a dry mass of 100 to $200 \mathrm{mg}$ (19). Thus, the number of nodules and dry mass found in this study are considered sufficient for BNF. The phenological stage of plant development at the beginning of symbiosis $\left(\mathrm{V}_{2}\right.$ to $\left.\mathrm{V}_{4}\right)(21)$, is also the best stage for the use of growth inhibitors. The number of nodes per plant is determined at this time, and the concentration of auxin at the plant apex is the highest (3). Thus, interference in these phenological stages has the greatest effects on architecture modification and change in growth patterns.

The root volume was not affected by the treatments for cultivar NA 5090 RG, presenting a volume of approximately $260 \mathrm{~cm}^{3} \mathrm{~m}^{-2}$; however, for the BMX Potência RR cultivar, application of $70 \mathrm{~g}$ a.i $\mathrm{ha}^{-1}$ of lactofen in phenological stage $\mathrm{V}_{3}+70 \mathrm{~g}$ a.i ha ${ }^{-1}$ of lactofen in phenological stage $\mathrm{V}_{6}$ (treatment $\mathrm{T}_{4}$ ) had a lower root volume $\left(188.61 \mathrm{~cm}^{3} \mathrm{~m}^{-2}\right)$, with a mean value of $235 \mathrm{~cm}^{3} \mathrm{~m}^{-2}$ (Table 2). This effect may be

Table 2. Roots characteristic of two soybean cultivars subjected to lactofen application.

\begin{tabular}{|c|c|c|c|c|}
\hline \multicolumn{5}{|c|}{ NA 5909 RG } \\
\hline Treatment & $\begin{array}{l}\text { Volume } \\
\left(\mathrm{cm}^{3} \cdot \mathrm{m}^{2}\right)\end{array}$ & $\begin{array}{c}\mathrm{SSA} \\
\left(\mathrm{cm}^{2} \cdot \mathrm{m}^{2}\right)\end{array}$ & $\begin{array}{l}\text { Dry mass } \\
(\text { g.m²) }\end{array}$ & $\begin{array}{c}\text { Length } \\
\text { (cm) }\end{array}$ \\
\hline $\mathrm{T} 1$ & $270.6^{\text {ns }}$ & $5557.8 \mathrm{~b}$ & $63.4^{\text {ns }}$ & $29.0 \mathrm{a}^{*}$ \\
\hline $\mathrm{T} 2$ & 247.9 & $6840.8 \mathrm{ab}$ & 60.1 & $28.0 \mathrm{a}$ \\
\hline T3 & 252.8 & $5512.9 \mathrm{~b}$ & 57.3 & $22.3 \mathrm{~b}$ \\
\hline $\mathrm{T} 4$ & 265.6 & $7917.1 \mathrm{a}$ & 65.0 & $21.2 \mathrm{~b}$ \\
\hline C.V. (\%) & 12.5 & 16.9 & 9.0 & 13.2 \\
\hline Significance & 0,7378 & 0,0321 & 0,2228 & 0,0360 \\
\hline \multicolumn{5}{|c|}{ BMX Potência RR } \\
\hline Treatment & $\begin{array}{l}\text { Volume } \\
\left(\mathrm{cm}^{3} \cdot \mathrm{m}^{2}\right)\end{array}$ & $\begin{array}{c}\text { SSA } \\
\left(\mathrm{cm}^{2} \cdot \mathrm{m}^{2}\right)\end{array}$ & $\begin{array}{c}\text { Dry mass } \\
\left(\text { g.m }{ }^{2}\right)\end{array}$ & $\begin{array}{c}\text { Length } \\
\text { (cm) }\end{array}$ \\
\hline $\mathrm{T} 1$ & $246.7 \mathrm{a}$ & $6533.2 \mathrm{~b}$ & $63.9 \mathrm{a}$ & $22.9^{\text {ns* }^{*}}$ \\
\hline $\mathrm{T} 2$ & $228.1 \mathrm{a}$ & $5317.3 \mathrm{c}$ & $57.4 \mathrm{ab}$ & 26.9 \\
\hline T3 & $231.1 \mathrm{a}$ & $3773.5 \mathrm{~d}$ & $47.9 \mathrm{c}$ & 27.3 \\
\hline $\mathrm{T} 4$ & $188.6 \mathrm{~b}$ & $8033.6 \mathrm{a}$ & $52.8 \mathrm{bc}$ & 24.9 \\
\hline C.V. (\%) & 11.7 & 11.5 & 9.7 & 12.4 \\
\hline Significance & 0,0451 & 0,0001 & 0,0128 & 0,3036 \\
\hline
\end{tabular}

Means followed by lowercase letters in the same column do not differ at a $\mathrm{p}>0,05$ by the Duncan test. ns: Non-significant. C.V.: Coefficient of variation. SSA: Specific surface area. T1- control 0; T2 - $140 \mathrm{~g}$ a.i ha-1 at phenological stage V3; T3 - $140 \mathrm{~g}$ a.i ha-1 at phenological stage V6; T4 - $70 \mathrm{~g} \mathrm{a.i} \mathrm{ha}^{-1}$ at phenological stage V3 + 70 $\mathrm{g}$ a.i ha ${ }^{-1}$ at phenological stage V6. ${ }^{*}$ - means per plant.

directly associated with energy reallocation from root growth towards recovery from the phytotoxicity induced by lactofen. Santos et al. (22) found reduced development of soybean roots when subjected to high doses of glyphosate, indicating that interference or phytotoxicity can lead to decreased root development. As well as, besides phytotoxicity, soybean plants submitted to application of the lactofen plus glyphosate showed lower plant height (23).

For the specific surface area (SSA) of roots in cultivar NA 5909 RG, treatments $\mathrm{T}_{4}$ (application of 70 $\mathrm{g}$ a.i ha ${ }^{-1}$ of lactofen in phenological stage $V_{3}+70 \mathrm{~g}$ a.i $\mathrm{ha}^{-1}$ of lactofen in phenological stage $V_{6}$ ), and $\mathrm{T}_{2}$ 
(application of $140 \mathrm{~g}$ a.i ha $\mathrm{ha}^{-1}$ of lactofen in phenological stage $V_{3}$ ) presented the highest values, 6840.85 and $7917.14 \mathrm{~cm}^{2} \mathrm{~m}^{-2}$, respectively (Table 2). For the cultivar BMX Potência RR, the root SSA was different for each of the treatments. The application of $70 \mathrm{~g}$ a.i ha ${ }^{-1}$ of lactofen in phenological stage $V_{3}+70$ $\mathrm{g}$ a.i ha ${ }^{-1}$ of lactofen in phenological stage $V_{6}$ (Treatment $\mathrm{T}_{4}$ ) presented the highest SSA (8033.58 $\mathrm{cm}^{2} \mathrm{~m}^{-2}$ ) and application of $140 \mathrm{~g}$ a.i ha-1 of lactofen in phenological stage $V_{6}$ (Treatment $T_{3}$ ) the lowest (3773.53 $\left.\mathrm{cm}^{2} \mathrm{~m}^{-2}\right)$; these values represent variability of approximately $46 \%$ between the two most distinct treatments (Table 2). The increase in SSA of the roots is highly beneficial because it increases soil exploration capacity, allowing for greater access to water and nutrients (23).

The root dry mass did not differ among the treatments for cultivar NA 5909 RG, however, for the BMX Potência RR cultivar, the control presented the highest dry mass (63.96 $\mathrm{g} \mathrm{m}^{-2}$ ) and application of 140 $\mathrm{g}$ a.i ha $\mathrm{h}^{-1}$ of lactofen in phenological stage $V_{6}$ (Treatment $\mathrm{T}_{3}$ ) the lowest (47.93 $\mathrm{g} \mathrm{m}^{-2}$ ) (Table 2). The control and application of $140 \mathrm{~g}$ a.i ha ${ }^{-1}$ of lactofen in phenological stage $V_{3}$ (Treatment $T_{2}$ ) had the highest root length for cultivar NA 5909 RG, with 29.02 and $28.03 \mathrm{~cm}$, respectively, compared to 22.34 and 21.16 $\mathrm{cm}$ for application of $140 \mathrm{~g}$ a.i ha $\mathrm{ha}^{-1}$ of lactofen in phenological stage $V_{6}$ (Treatment $T_{3}$ ) and application of $70 \mathrm{~g}$ a.i ha ${ }^{-1}$ of lactofen in phenological stage $V_{3}+70$ $\mathrm{g}$ a.i ha $\mathrm{a}^{-1}$ of lactofen in phenological stage $V_{6}$ ( Treatment $\mathrm{T}_{4}$ ) (Table 2). The greater the root development at depth, the higher the plant's ability to seek water at depths under water stress conditions (24). The root length of cultivar BMX Potência RR did differ among the treatments, presenting a mean of 25 cm (Table 2).

The amount of photosynthetically active radiation intercepted in the upper layer of the plants was not affected by the treatments in either cultivar

Table 3. Interception of photosynthetically active radiation per plant third and light extinction coefficient (k) at phenological stage R2 of two soybean cultivars subjected to lactofen application

\begin{tabular}{|c|c|c|c|}
\hline \multicolumn{4}{|c|}{ NA 5909 RG } \\
\hline Treatment & $\begin{array}{c}\text { Upper } \\
\left(\mu \mathrm{mol} . \mathrm{m}^{2} \cdot \mathrm{s}^{-1}\right)\end{array}$ & $\begin{array}{c}\text { Lower } \\
\left(\mu \mathrm{mol} . \mathrm{m}^{2} \cdot \mathrm{s}^{-1}\right)\end{array}$ & $\begin{array}{c}\text { Extinction coefficient } \\
\text { (k) }\end{array}$ \\
\hline $\mathrm{T} 1$ & $1525.8^{\mathrm{ns}^{*}}$ & $99.4 \mathrm{~b}$ & $0.6^{\mathrm{ns}}$ \\
\hline $\mathrm{T} 2$ & 1479.9 & $134.4 \mathrm{a}$ & 0.6 \\
\hline T3 & 1430.9 & $137.6 \mathrm{a}$ & 0.5 \\
\hline $\mathrm{T} 4$ & 1467.8 & $122.2 \mathrm{a}$ & 0.4 \\
\hline C.V. (\%) & 3.4 & 13.1 & 15.6 \\
\hline Significance & 0,1738 & 0,0317 & 0,0765 \\
\hline \multicolumn{4}{|c|}{ BMX Potência RR } \\
\hline Treatment & $\begin{array}{c}\text { Upper } \\
\left(\mu \mathrm{mol} . \mathrm{m}^{2} . \mathrm{s}^{-1}\right)\end{array}$ & $\begin{array}{c}\text { Lower } \\
\left(\mu \mathrm{mol} \cdot \mathrm{m}^{2} \cdot \mathrm{s}^{-1}\right)\end{array}$ & $\begin{array}{c}\text { Extinction coefficient } \\
\text { (k) }\end{array}$ \\
\hline $\mathrm{T} 1$ & $1758.9^{\text {ns* }^{*}}$ & $85.4 \mathrm{~b}$ & $0.9^{\text {ns }}$ \\
\hline $\mathrm{T} 2$ & 1677.8 & $123.3 \mathrm{a}$ & 0.7 \\
\hline T3 & 1682.3 & $130.3 \mathrm{a}$ & 0.8 \\
\hline $\mathrm{T} 4$ & 1693.0 & $131.9 \mathrm{a}$ & 0.8 \\
\hline C.V. (\%) & 4.1 & 10.1 & 15.7 \\
\hline Significance & 0,3514 & 0,0017 & 0,1242 \\
\hline
\end{tabular}

Means followed by lowercase letters in the same column do not differ at a $\mathrm{p}>0,05$ by the Duncan test. ns: Non-significant. C.V.: Coefficient of variation. k: extinction coefficient. Treatments: T1control 0; T2 - $140 \mathrm{~g}$ a.i ha ${ }^{-1}$ at phenological stage V3; T3 $140 \mathrm{~g}^{\text {a.i ha }} \mathrm{h}^{-1}$ at phenological stage V6; T4 - $70 \mathrm{~g}^{\text {a.i }} \mathrm{ha}^{-1}$ at phenological stage V3 + $70 \mathrm{~g}$ a.i ha ${ }^{-1}$ at phenological stage V6. * - means per plant.
(Table 3). However, an interception in the lower layer was affected (Table 3). The treatments that received lactofen application presented a mean increase in the interception of solar radiation of 32 and $34 \mu \mathrm{mol} \mathrm{m}{ }^{2} . \mathrm{s}^{-}$ 1 for NA 5909 RG and BMX Potência RR, respectively (Table 3). This effect is directly related to the change in plant architecture. Soybean cultivars that present excessive growth easily suffers from inefficient use of solar radiation (25).

With the use of lactofen, a 15\% increase in the interception of photosynthetically active radiation was observed in the lower plant stratum for cultivar NA 5909 RG in comparison to the control. Similarly, an increase of $33 \%$ was observed for cultivar BMX Potência RR (Table 3). There was no difference in the light extinction coefficient $(\mathrm{k})$ among the treatments for either cultivar (Table 3).

Due to change in plant architecture resulting from lactofen, the lower layer of plants received a greater amount of solar radiation, making them photosynthetically more efficient. Plants with greater photosynthetic efficiency, especially in the grainfilling period, are more productive and tend to express their productive potential more easily (26). The greater interception of solar radiation via the change in architecture generally led to increased productivity (3). Thus, to provide a greater amount of light for soybean plants at the beginning of flowering allows for a greater number of effective pods at the end of the cycle (3). Consequently, there is increase yield, and this response is caused mainly by the maintenance of photosynthesis in leaves in the lower plant part.

The percent area covered and the number of droplets per $\mathrm{cm}^{2}$ applied by spraying was affected by the treatments, primarily in the middle and lower plant layers for the two cultivars studied (Table 4). In the middle layer of cultivar NA 5909 RG, all of the treatments that received lactofen application presented a greater coverage percentage and a greater number of droplets per $\mathrm{cm}^{2}$ compared to the control (Table 4). The results for cultivar BMX Potência RR were similar, with the control presenting the lowest percent covered area in comparison with the other treatments. The control did not differ from treatments $\mathrm{T}_{3}$ (application of $140 \mathrm{~g}^{\text {a.i ha }}{ }^{-1}$ of lactofen in phenological stage $\mathrm{V}_{6}$ ) and $\mathrm{T}_{4}$ (application of $70 \mathrm{~g}$ a.i ha ${ }^{-1}$ of lactofen in phenological stage $V_{3}+70 \mathrm{~g}$ a.i $\mathrm{ha}^{-1}$ of lactofen in phenological stage $V_{6}$ ) regarding the number of droplets per $\mathrm{cm}^{2}$ (Table 4).

In general, the upper layer of the plant intercepts a high number of droplets and has a larger area covered than is necessary (27). The deposition of spray droplets in soybean stage R1 in the apical region was almost three times higher than in the basal region (28). Moreover, spray depositions in the lower layer were significantly lower than the upper layer (27).

In the lower plant layer, the application of lactofen increased the percent coverage and number of droplets per $\mathrm{cm}^{2}$ when compared to the control. This effect was greater than $100 \%$ for both cultivars. The largest differences between treatments were observed in the lower layer of the plants, where 
application of $140 \mathrm{~g}$ a.i ha $\mathrm{h}^{-1}$ of lactofen in phenological stage $V_{3}$ (Treatment $T_{2}$ ) produced the greatest effect (Table 4). In cultivar NA 5909 RG, application of $140 \mathrm{~g}$ a.i ha ${ }^{-1}$ of lactofen in phenological stage $V_{3}$ compared to the control showed a 16-fold increase in the percent coverage and a 12-fold increase in the number of droplets per $\mathrm{cm}^{2}$. For cultivar, BMX Potência RR, the per cent coverage was 20-fold higher, and the number of droplets per $\mathrm{cm}^{2}$ was 14-

Table 4. Deposition of droplets on leaves of the soybean cultivars in the different plant thirds at phenological stage R2 under different lactofen applications

\begin{tabular}{|c|c|c|c|c|c|c|}
\hline \multicolumn{7}{|c|}{ NA 5909 RG } \\
\hline \multirow[b]{2}{*}{$\begin{array}{l}\text { Treat- } \\
\text { ment }\end{array}$} & \multicolumn{2}{|c|}{ Upper third } & \multicolumn{2}{|c|}{ Middle third } & \multicolumn{2}{|c|}{ Lower third } \\
\hline & $\begin{array}{l}\text { Covered } \\
\text { area (\%) }\end{array}$ & $\begin{array}{c}\text { Droplets } \\
\text { cm }^{2}\end{array}$ & $\begin{array}{l}\text { Covered } \\
\text { area (\%) }\end{array}$ & $\begin{array}{c}\text { Droplets } \\
\text { cm }^{2}\end{array}$ & $\begin{array}{l}\text { Covered } \\
\text { area (\%) }\end{array}$ & $\begin{array}{c}\text { Droplets } \\
\text { cm }^{2}\end{array}$ \\
\hline $\mathrm{T} 1$ & $28.8^{\mathrm{ns}^{*}}$ & $232.7^{\text {ns }}$ & $7.2 \mathrm{~b}$ & $56.6 \mathrm{~b}$ & $1.1 \mathrm{~d}$ & $10.6 \mathrm{~d}$ \\
\hline $\mathrm{T} 2$ & 27.57 & 194.6 & $18.3 \mathrm{a}$ & $129.5 \mathrm{a}$ & $17.3 \mathrm{a}$ & $130.2 \mathrm{a}$ \\
\hline $\mathrm{T} 3$ & 20.9 & 186.2 & $18.1 \mathrm{a}$ & $129.9 \mathrm{a}$ & $8.9 \mathrm{c}$ & $71.1 \mathrm{c}$ \\
\hline T4 & 29.9 & 238.4 & $21.3 \mathrm{a}$ & $154.6 \mathrm{a}$ & $12.7 \mathrm{~b}$ & $96.4 \mathrm{~b}$ \\
\hline $\begin{array}{l}\text { C.V. } \\
(\%)\end{array}$ & 23.45 & 16.9 & 20.3 & 26.0 & 18.4 & 23.6 \\
\hline $\begin{array}{l}\text { Signifi- } \\
\text { cance }\end{array}$ & 0,2460 & 0,1507 & 0,0009 & 0,0095 & 0,0000 & 0,0000 \\
\hline \multicolumn{7}{|c|}{ BMX Potência RR } \\
\hline \multirow[b]{2}{*}{$\begin{array}{l}\text { Treat- } \\
\text { ment }\end{array}$} & \multicolumn{2}{|c|}{ Upper third } & \multicolumn{2}{|c|}{ Middle third } & \multicolumn{2}{|c|}{ Lower third } \\
\hline & $\begin{array}{l}\text { Covered I } \\
\text { area (\%) }\end{array}$ & $\begin{array}{c}\text { Droplets } \\
\text { cm }^{2}\end{array}$ & $\begin{array}{l}\text { Covered } \\
\text { area (\%) }\end{array}$ & $\begin{array}{c}\text { Droplets } \\
\text { cm }^{2}\end{array}$ & $\begin{array}{l}\text { Covered } \\
\text { area (\%) }\end{array}$ & $\begin{array}{c}\text { Droplets } \\
\text { cm }^{2}\end{array}$ \\
\hline T1 & $30.8^{\mathrm{ns}^{*}}$ & $233.0^{\mathrm{ns}}$ & $8.0 \mathrm{c}$ & $72.5 \mathrm{~b}$ & $1.4 \mathrm{c}$ & $8.2 \mathrm{c}$ \\
\hline $\mathrm{T} 2$ & 34.0 & 263.2 & $22.2 \mathrm{a}$ & $159.0 \mathrm{a}$ & $21.4 \mathrm{a}$ & $123.5 \mathrm{a}$ \\
\hline T3 & 31.1 & 268.1 & $15.4 \mathrm{~b}$ & $89.5 \mathrm{ab}$ & $9.0 \mathrm{~b}$ & $81.7 \mathrm{~b}$ \\
\hline $\mathrm{T} 4$ & 33.1 & 300.8 & $15.9 \mathrm{~b}$ & $133.2 \mathrm{ab}$ & $11.2 \mathrm{~b}$ & $92.1 \mathrm{~b}$ \\
\hline $\begin{array}{l}\text { C.V. } \\
\text { (\%) }\end{array}$ & 8.4 & 19.2 & 23.3 & 40.5 & 16.5 & 15.8 \\
\hline $\begin{array}{c}\text { Signifi- } \\
\text { cance }\end{array}$ & 0,3050 & 0,3592 & 0,0026 & 0,0688 & 0,0000 & 0,0000 \\
\hline
\end{tabular}

Means followed by lowercase letters in the same column do not differ at a $p>0,05$ by the Duncan test. ns: Non-significant. C.V.: Coefficient of variation. Treatments: T1- control 0; T2 - $140 \mathrm{~g}$ a.i ha ${ }^{-1}$ at phenological stage V3; T3 - $140 \mathrm{~g}$ a.i ha $^{-1}$ at phenological stage V6; $\mathrm{T} 4-70 \mathrm{~g}$ a.i ha ${ }^{-1}$ at phenological stage V3 $+70 \mathrm{~g}$ a.i ha ${ }^{-1}$ at phenological stage V6. * - means per plant.

fold higher than the control condition (Table 4).

The product deposition in the soybean canopy provided by fungicide application in the lower part is generally low resulting in inefficient disease control (29). Therefore, it is necessary to develop strategies to increase the deposition of herbicide spray droplets on the lower part of the canopy. In this way, soybean cultivars with low height, branch number, and leaf area index exhibited more product deposition in the middle and lower canopy layers (30).

The number of pods in the upper layer of the plants was affected by the treatments only in cultivar BMX Potência RR, where application of $140 \mathrm{~g}^{\mathrm{a}}$.i ha $\mathrm{ha}^{-1}$ of lactofen in phenological stage $V_{3}$ (Treatment $T_{2}$ ) presented the largest number of pods compared to the control (Table 5). This variable was not affected by the treatments in either cultivar in the middle layer of the plant (Table 5). The lower layer of the plant presented similar results for the two cultivars, and treatment $\mathrm{T}_{2}$ presented the largest number of pods, 5.86 and 13.26 for NA 5909 RG and BMX Potência RR, respectively (Table 5). The total number of pods per plant differed among treatments only for cultivar BMX Potência RR, where application of $140 \mathrm{~g}$ a.i ha ${ }^{-1}$ of lactofen in phenological stage $\mathrm{V}_{3}$ (Treatment $\mathrm{T}_{2}$ ), with 55.44 pods, again presented the highest number (Table 5).

The number of empty pods in the upper layer of the plants differed among treatments for both compared to 4.3 for the mean of the other treatments (Table 5). The number of empty pods in the middle

Table 5. Number of pods and empty pods in the different thirds of two soybean cultivars subjected to lactofen application

\begin{tabular}{|c|c|c|c|c|}
\hline \multicolumn{5}{|c|}{ Number of pods } \\
\hline \multicolumn{5}{|c|}{ NA 5909 RG } \\
\hline Treatment & Upper third & Middle third & Lower third & Total pods plant $^{-1}$ \\
\hline $\mathrm{T} 1$ & $19.7^{\mathrm{ns}^{*}}$ & $33.6^{\text {ns }}$ & $3.3 \mathrm{~b}$ & $56.6^{\mathrm{ns}}$ \\
\hline $\mathrm{T} 2$ & 18.6 & 29.7 & $5.9 \mathrm{a}$ & 54.2 \\
\hline T3 & 20.7 & 35.0 & $4.3 \mathrm{~b}$ & 60.0 \\
\hline $\mathrm{T} 4$ & 17.7 & 31.2 & $3.1 \mathrm{~b}$ & 52.1 \\
\hline C.V. (\%) & 15.0 & 21.0 & 23.9 & 17.3 \\
\hline Significance & 0,4840 & 0,6853 & 0,0143 & 0,9346 \\
\hline \multicolumn{5}{|c|}{ BMX Potência RR } \\
\hline Treatment & Upper third & Middle third & Lower third & Total pods plant $^{-1}$ \\
\hline $\mathrm{T} 1$ & $12.6 \mathrm{~b}^{*}$ & $23.9^{\text {ns }}$ & $8.7 \mathrm{~b}$ & $45.2 \mathrm{~b}$ \\
\hline $\mathrm{T} 2$ & $15.5 \mathrm{a}$ & 26.6 & $13.3 \mathrm{a}$ & $55.4 \mathrm{a}$ \\
\hline T3 & $14.4 \mathrm{ab}$ & 24.9 & $8.1 \mathrm{~b}$ & $47.3 \mathrm{~b}$ \\
\hline $\mathrm{T} 4$ & $13.4 \mathrm{ab}$ & 25.9 & $9.3 \mathrm{~b}$ & $48.6 \mathrm{ab}$ \\
\hline C.V. (\%) & 13.0 & 13.2 & 24.07 & 10.4 \\
\hline Significance & 0,0351 & 0,6751 & 0,0598 & 0,0829 \\
\hline \multicolumn{5}{|c|}{ Number of empty pods } \\
\hline \multicolumn{5}{|c|}{ NA 5909 RG } \\
\hline Treatment & Upper third & Middle third & Lower third & $\begin{array}{c}\text { Total empty pods } \\
\text { plant }^{-1}\end{array}$ \\
\hline $\mathrm{T} 1$ & $5.1 a^{*}$ & $10.3^{\text {ns }}$ & $1.2 \mathrm{~b}$ & $16.7^{\text {ns }}$ \\
\hline $\mathrm{T} 2$ & $4.1 \mathrm{~b}$ & 8.6 & $2.6 \mathrm{a}$ & 15.3 \\
\hline T3 & $4.1 \mathrm{~b}$ & 12.0 & $1.2 \mathrm{~b}$ & 17.6 \\
\hline $\mathrm{T} 4$ & $3.7 \mathrm{~b}$ & 9.6 & $1.1 \mathrm{~b}$ & 14.3 \\
\hline C.V. (\%) & 16.4 & 24.4 & 23.5 & 19.6 \\
\hline Significance & 0,0664 & 0,3381 & 0,0005 & 0,4773 \\
\hline \multicolumn{5}{|c|}{ BMX Potência RR } \\
\hline Treatment & Upper third & Middle third & Lower third & $\begin{array}{l}\text { Total empty } \\
\text { pods plant }^{-1}\end{array}$ \\
\hline $\mathrm{T} 1$ & $3.1 c^{*}$ & $5.1 \mathrm{~b}$ & $2.7 \mathrm{~b}$ & $10.9 \mathrm{c}$ \\
\hline $\mathrm{T} 2$ & $4.5 \mathrm{ab}$ & $7.9 \mathrm{a}$ & $4.1 \mathrm{a}$ & $16.4 \mathrm{a}$ \\
\hline T3 & $3.9 \mathrm{~b}$ & $6.7 \mathrm{ab}$ & $2.1 \mathrm{~b}$ & $13.2 \mathrm{bc}$ \\
\hline $\mathrm{T} 4$ & $4.6 \mathrm{a}$ & $7.3 \mathrm{a}$ & $3.4 \mathrm{~b}$ & $15.2 \mathrm{ab}$ \\
\hline C.V. (\%) & 11.4 & 20.4 & 17.5 & 12.8 \\
\hline Significance & 0,0048 & 0,0734 & 0,0031 & 0,0091 \\
\hline
\end{tabular}

Means followed by lowercase letters in the same column do not differ at a $\mathrm{p}>0,05$ by the Duncan test. ns: Non-significant. C.V.: Coefficient of variation. Treatments: T1- control 0; T2 - $140 \mathrm{~g}$ a.i ha ${ }^{-1}$ at phenological stage V3; T3 - $140 \mathrm{~g}$ a.i ha $^{-1}$ at phenological stage V6; $\mathrm{T} 4-70 \mathrm{~g}$ a.i ha ${ }^{-1}$ at phenological stage V3 $+70 \mathrm{~g}$ a.i ha ${ }^{-1}$ at phenological stage V6. * - means per plant.

layer of cultivar NA 5909 RG did not differ among the treatments. BMX Potência RR followed the same pattern for the upper layer, where the control was the treatment with the lowest number of empty pods, with a mean of 5.12 and the other treatments exhibiting a mean of 7.31 (Table 5). The greatest treatment effect was observed on the lower layer of the plants, and in the application of $140 \mathrm{~g} \mathrm{a.i} \mathrm{ha}^{-1}$ of lactofen in phenological stage $V_{3}$ (Treatment $T_{2}$ ) resulted in the highest number of empty pods for the two cultivars (Table 5). The total number of empty pods per plant did not differ among treatments for cultivar NA 5909 RG, while the control was the treatment that presented the lowest number of empty pods per plant for cultivar BMX Potência RR (Table 5). 
There was no difference in the number of grains per plant among the treatments in the upper and middle layers for both cultivars (Table 6). There were differences among treatments in the lower layer, with the highest number of grains in the application of $140 \mathrm{~g}$ a.i ha ${ }^{-1}$ of lactofen in phenological stage $V_{3}$ (Treatment $T_{2}$ ) for both cultivars (Table 6). Compared with the control group, which generally presented the lowest values for this variable, the percent increases in the number of grains in the lower layer were approximately 50\% and 34\% for cultivars NA 5009 RG and BMX Potência RR, respectively. This higher grain yield in the lower layer of the plants is due to the decrease in apical dominance and reduction in height. The removal of the apical meristem from soybean plants at $25 \mathrm{~cm}$ in height increased the grain yield (31). There is improved photosynthetically active radiation interception with this reduction in height, especially in the lower layer, increasing the net carbon

Table 6. Number of grains and grain weight in different plant thirds of two soybean cultivars subjected to lactofen application

\begin{tabular}{|c|c|c|c|c|c|c|}
\hline \multicolumn{7}{|c|}{ NA 5909 RG } \\
\hline \multirow{2}{*}{ Treatment } & \multicolumn{3}{|c|}{ Grains per third } & \multicolumn{3}{|c|}{ Grain weight per third (g) } \\
\hline & Upper & Middle & Lower & Upper & Middle & Lower \\
\hline $\mathrm{T} 1$ & $51.2^{\mathrm{ns}^{*}}$ & ${ }^{*} 85.9^{\text {ns }}$ & $7.8 \mathrm{c}$ & $7.9^{\text {ns }}$ & $12.9^{\text {ns }}$ & $1.4 \mathrm{~b}$ \\
\hline $\mathrm{T} 2$ & 48.0 & 77.4 & $14.7 \mathrm{a}$ & 7.9 & 12.1 & $2.5 \mathrm{a}$ \\
\hline T3 & 53.8 & 91.1 & $10.0 \mathrm{~b}$ & 8.6 & 13.2 & $1.5 \mathrm{~b}$ \\
\hline $\mathrm{T} 4$ & 44.7 & 79.9 & $7.5 \mathrm{c}$ & 7.4 & 13.5 & $1.4 \mathrm{~b}$ \\
\hline C.V. (\%) & 15.2 & 21.2 & 14.2 & 20.4 & 23.9 & 17.4 \\
\hline Significance & 0,4242 & 0,7935 & 0,0002 & 0,7636 & 0,9522 & 0,0005 \\
\hline \multicolumn{7}{|c|}{ BMX Potência RR } \\
\hline \multirow{2}{*}{ Treatment } & \multicolumn{3}{|c|}{ Grains per third } & \multicolumn{3}{|c|}{ Grain weight per third (g) } \\
\hline & Upper & Middle & Lower & Upper & Middle & Lower \\
\hline $\mathrm{T} 1$ & $35.9^{\mathrm{ns}^{*}}$ & $65.1^{\mathrm{ns}}$ & $22.7 \mathrm{~b}$ & $4.8^{\mathrm{ns}}$ & $9.8^{\text {ns }}$ & $3.6 \mathrm{~b}$ \\
\hline $\mathrm{T} 2$ & 44.4 & 73.0 & $34.6 \mathrm{a}$ & 5.5 & 9.8 & $4.6 \mathrm{a}$ \\
\hline T3 & 40.8 & 70.4 & $21.5 \mathrm{~b}$ & 5.2 & 10.5 & $3.0 \mathrm{~b}$ \\
\hline $\mathrm{T} 4$ & 37.5 & 70.6 & $23.9 \mathrm{~b}$ & 5.0 & 9.5 & $3.3 \mathrm{~b}$ \\
\hline C.V. (\%) & 13.7 & 12.4 & 14.7 & 17.1 & 13.6 & 16.9 \\
\hline Significance & 0,1602 & 0,6461 & 0,0021 & 0,7131 & 0,7531 & 0,0523 \\
\hline
\end{tabular}

Means followed by lowercase letters in the same column do not differ at a $p>0,05$ by the Duncan test. ns: Non-significant. C.V.: Coefficient of variation. Treatments: T1- control 0; T2 - $140 \mathrm{~g} \mathrm{a.i} \mathrm{ha}^{-1}$

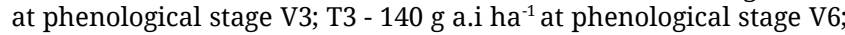
$\mathrm{T} 4-70 \mathrm{~g}$ a.i ha ${ }^{-1}$ at phenological stage V3 $+70 \mathrm{~g}$ a.i ha $\mathrm{ha}^{-1}$ at phenological stage $\mathrm{V} 6$. $^{*}$ - means per plant.

assimilation of the leaves in this layer. Thus, the plants are more productive when compared with those that did not receive lactofen application.

The grain weight per plant in the different layers followed the same pattern as the number of grains, where only the lower layer differed among the treatments (Table 6). The treatment that showed the highest values was again application of $140 \mathrm{~g}$ a.i $\mathrm{ha}^{-1}$ of lactofen in phenological stage $\mathrm{V}_{3}$ (Treatment $\mathrm{T}_{2}$ ), with a mean of $2.52 \mathrm{~g}$ for NA $5909 \mathrm{RG}$ and $4.56 \mathrm{~g}$ for BMX Potência RR. The means for the other treatments were $1.43 \mathrm{~g}$ and $3.30 \mathrm{~g}$ respectively, and did not differ significantly from each other (Table 6). When lactofen is applied in phenological stage $V_{3}$, the effect of breaking the apical dominance of the plants is greater due to the higher concentration of auxin in the apex of the plants at this stage, thereby attaining greater modification in plant architecture (32).
Table 7. Thousand-grain weight and grains yield of two soybean cultivars subjected to lactofen application

\begin{tabular}{|c|c|c|}
\hline \multicolumn{3}{|c|}{ NA 5909 RG } \\
\hline Treatment & TGW (g) & $\begin{array}{l}\text { Grain yield } \\
\left(\mathrm{kg} \mathrm{ha}^{-1}\right)\end{array}$ \\
\hline $\mathrm{T} 1$ & $183.2^{\mathrm{ns}^{*}}$ & $4890.5 \mathrm{~b}$ \\
\hline $\mathrm{T} 2$ & 177.7 & $5072.0 \mathrm{a}$ \\
\hline T3 & 175.6 & $4839.3 \mathrm{~b}$ \\
\hline $\mathrm{T} 4$ & 179.8 & $4938.0 \mathrm{ab}$ \\
\hline C.V. (\%) & 6.2 & 2.40 \\
\hline Significance & 0,8473 & 0,0876 \\
\hline \multicolumn{3}{|c|}{ BMX Potência RR } \\
\hline Treatment & TGW (g) & $\begin{array}{l}\text { Grain yield } \\
\left(\mathrm{kg} \mathrm{ha}^{-1}\right)\end{array}$ \\
\hline $\mathrm{T} 1$ & $152.6^{\mathrm{ns}^{*}}$ & $4168.5 \mathrm{bc}$ \\
\hline $\mathrm{T} 2$ & 151.9 & $4424.4 \mathrm{a}$ \\
\hline T3 & 154.0 & $4299.6 \mathrm{ab}$ \\
\hline $\mathrm{T} 4$ & 151.4 & $4052.5 \mathrm{c}$ \\
\hline C.V. (\%) & 2.1 & 3.9 \\
\hline Significance & 0,7017 & 0,0591 \\
\hline
\end{tabular}

Means followed by lowercase letters in the same column do not differ at a $p>0,05$ by the Duncan test. ns: Non-significant. TGW: thousand-grain weight; C.V.: Coefficient of variation. Treatments: T1- control 0; T2 - $140 \mathrm{~g}$ a.i ha ${ }^{-1}$ at phenological stage V3; T3 - $140 \mathrm{~g}$ a.i ha ${ }^{-1}$ at phenological stage V6; T4 - $70 \mathrm{~g}^{\mathrm{a} . \mathrm{i}} \mathrm{ha}^{-1}$ at phenological stage V3 + $70 \mathrm{~g}$ a.i ha ${ }^{-1}$ at phenological stage V6. * - means per plant.

The thousand-grain weight did not differ among the treatments for either cultivar, but there was a difference in the grain yield per hectare (Table 7). The treatment that resulted in the highest productivity in relation to the control was application of $140 \mathrm{~g}$ a.i ha ${ }^{-1}$ of lactofen in phenological stage $V_{3}$ (Treatment $\mathrm{T}_{2}$ ) (Table 7). Cultivar NA 5909 RG showed an increase in yield of $181 \mathrm{~kg} \mathrm{ha}^{-1}$, and cultivar BMX Potência RR showed an increase of $255 \mathrm{~kg} \mathrm{ha}^{-1}$ (Table 7). The other treatments presented no significant difference in relation to the control (Table 7).

This low productivity often occurs due to deficiencies in phytosanitary control and is exacerbated due to the low interception of solar radiation caused by excessive plant growth, which causes canopy-shading (33). Thus, in soybean plants, the high deposition of phytosanitary products and solar radiation in the lower layer showed a superior yield of grains in this stratum (34). Therefore, plant varieties with traits resistant to diseases, which decreases yield losses, increase profit and result in more production of food are necessary (35).

\section{Conclusion}

In soybean cultivars the interception of photosynthetically active radiation in the lower layer increased in all treatments tested. Lactofen application increased the percent area covered and the number of phytosanitary products spray droplets per $\mathrm{cm}^{2}$ in the middle and lower layers of the plants. Moreover, the results showed that the use of lactofen as a growth inhibitor in phenological stage $V_{3}$ increases the productive efficiency of soybean due to changes to plant architecture and root development. Future research using lactofen in different phenological stages and cultivars may provide more insights into the performance of this growth inhibitor in soybean. 


\section{Authors' contributions}

da RWP participated in the design of the study, conducted the experiment, performed all the evaluations and the statistical analysis. AC helped to writing the manuscript and also in the discussion of the results. GC conceived of the study, participated in its design and coordination as well as revision of the manuscript. All authors read and approved the final manuscript.

\section{Acknowledgements}

The authors are grateful to Coordenação de Aperfeiçoamento de Pessoal de Nível Superior (CAPES) for financial support, PNPD/CAPES for the scholarship of AC and Prosup/CAPES scholarship of da RWP.

\section{Conflict of interests}

The authors declare that they have no competing interests.

\section{References}

1. El-Hamidi M, Zaher FA. Production of vegetable oils in the world and in Egypt: an overview. Bulletin of the National Research Centre. 2018;42(1):19. https://doi.org/10.1186/s42269018-0019-0

2. Biabani A, Hashemi M, Herbert SJ. Agronomic performance of two intercropped soybean cultivars. International Journal of Plant Production. 2008;2(3):215-22. https://doi.org/10.22069/ IJPP.2012.614

3. Liu B, Liu XB, Wang C, Jin J, Herbert SJ, Hashemi M. Responses of soybean yield and yield components to light enrichment and planting density. International Journal of Plant Production. 2010;4(1):1-10.

4. Nuyttens D, Baetens K, De Schampheleire M, Sonck B. Effect of nozzle type, size and pressure on spray droplet characteristics. Biosystems Engineering. 2007;97(3):333-45. https://doi.org/ 10.1016/j.biosystemseng.2007.03.001

5. Espindula MC, Rocha VS, Souza LT de, Souza MA de, Grossi JAS. Efeitos de reguladores de crescimento na elongação do colmo de trigo. Acta Scientiarum Agronomy. 2010;32(1):109-16. https://doi.org/10.4025/actasciagron.v32i1.943

6. Chavarria G, da Rosa WP, Hoffmann L, Durigon MR. Regulador de crescimento em plantas de trigo: Reflexos sobre o desenvolvimento vegetativo, rendimento e qualidade de grãos. Revista Ceres. 2015;62(6):583-88. https://doi.org/10.1590/0034737X201562060011

7. Leite GHP, Crusciol CAC, Silva MDA. Desenvolvimento e produtividade da cana-de-açúcar após aplicação de reguladores vegetais em meio de safra. Semina: Ciências Agrárias. 2011;32(1):129-38. 0359.2011v32n1p129 https://doi.org/10.5433/1679

8. Nagashima GT, Miglioranza E, Marur CJ, Yamaoka RS, Silva JGR. Development of cotton in response to mode of application and doses of mepiquat chloride in seeds. Ciencia Rural. 2010;40(1):007-11. 84782009005000236

https://doi.org/10.1590/S0103

9. Nelson KA, Rottinghaus GE, Nelson TE. Effect of lactofen ap plication timing on yield and isoflavone concentration in soybean seed. Agronomy Journal. 2007;99(3):645-49. https:// doi.org/10.2134/agronj2006.0067

10. Gallon M, Buzzello GL, Trezzi MM, Diesel F, Silva HL Da. Ação de herbicidas inibidores da PROTOX sobre o desenvolvimento, acamamento e produtividade da soja. Revista Brasileira de
Herbicidas. 2016;15(3):232-40. https://doi.org/10.7824/rbh.v15i3.471

11. Orlowski JM, Gregg GL, Lee CD, Serson WR. Early-season lactofen application fails to increase soybean yield under weed-free conditions. Agronomy Journal. 2016;108(4):1552-60. https://doi.org/10.2134/agronj2015.0589

12. Graham MY. The diphenylether herbicide lactofen induces cell death and expression of defense-related genes in soybean Plant Physiology. 2005;139:1784-94. https://doi.org/10.1104/ pp.105.068676

13. Fehr WR, Caviness CE, Burmood DT, Pennington JS. Stage of development descriptions for soybeans, Glycine $\max (\mathrm{L}$.$) Mer-$ rill 1. Crop Science. 1971;11(6):929-31. https://doi.org/10.2135/ cropsci1971.0011183X001100060051X

14. ASABE. Spray nozzle classification by droplet spectra. ANSI/ ASAE S5721 W/Corr1. 2009;389-81.

15. Caverzan A, Giacomin R, Müller M, Biazus C, Lângaro NC, Chavarria G. How does seed vigor affect soybean yield components? Agronomy Journal. 2018;110(4):1318-27. https:/ doi.org/10.2134/agronj2017.11.0670

16. Cannell RQ. Methods of studying root systems. By W. Böhm. Berlin: Springer. 1979; pp. 200, DM 69, \$38.00. Experimental Agriculture. 1980;16(4):437. https://doi.org/10.1017/ S0014479700012126

17. Moojen TMBM, Cavalcante RBL, Mendes CAB Avaliação da radiação solar com base em dados de nebulosidade. Geografia. 2012;21(3):41-55. 1747.2012v21n3p41 https://doi.org/10.5433/2447-

18. Costa C, Castoldi FL. CoStat: um programa para quem pensa que não gosta de estatística. $1^{\text {st }}$ ed. Passo Fundo. 2009; 384 p.

19. Souza RA de, Hungria M, Franchini JC, Maciel CD, Campo RJ, Zaia DAM. Conjunto mínimo de parâmetros para avaliação da microbiota do solo e da fixação biológica do nitrogênio pela soja. Pesquisa Agropecuária Brasileira. 2008;43(1):83-91. https://doi.org/10.1590/S0100-204X2008000100011

20. Tironi SP, Reis MR, Galon L, Freitas MAM, Costa MD, Silva AA et al. Action of herbicides on the activity of phosphate-solubilizing bacteria isolated from sugarcane rhizosphere. Planta Daninha. 2009;27(4):747-54. https://doi.org/10.1590/S0100 83582009000400013

21. Santos JB, Santos EA, Fialho CMT, Silva AA, Freitas MAM. Influence of desiccation time before sowing on the development of soybean resistant to glyphosate. Planta Daninha. 2007;25(4):869-75. https://doi.org/10.1590/S0100 83582007000400024

22. Cesco VJS, Albrecht AJP, Rodrigues DM, Krenchinski FH, Albrecht LP. Associations between herbicides and glyphosate in agronomic performance of RR2 intact soybean. Planta Daninha. 2018;36. https://doi.org/10.1590/s0100 83582018360100015

23. Lynch JP. Roots of the second green revolution. Australian Journal of Botany. 2007;55(5):493-512. https://doi.org/10.1071/ BT06118

24. Souza CA, Figueiredo BP, Coelho CMM, Casa RT, Sangoi L. Plant architecture and productivity of soybean affected by plant growth retardants. Bioscience Journal. 2013;29(3):634-43.

25. Casaroli D, Fagan EB, Simon J, Medeiros SP, Manfron PA, Neto DD, et al. Radiação solar e aspectos fisiológicos na cultura de soja - uma revisão. Revista da FZVA. 2007;14(2):102-20.

26. Boschini L, Contiero RL, Macedo Junior EK, Guimarães VF. Avaliação da deposição da calda de pulverização em função da vazão e do tipo de bico hidráulico na cultura da soja. Acta Scientiarum Agronomy. 2008;30(2):171-75. https://doi.org/10.4025/ actasciagron.v30i2.1789

27. Farinha JV, Martins D, Costa NV, Domingos VD. Spray depos ition on soybean varietes at R1 grow stage. Ciencia Rural. 2009;39(6):1738-44. 84782009000600016 https://doi.org/10.1590/S0103

28. da Cunha JPAR, Moura EAC, Da Silva JL, Zago FA, Juliatti FC. Spray nozzle effect on soybean rust chemical control. Engenharia Agricola. 2008;28(2):283-91. https://doi.org/10.1590/S010069162008000200009 
29. Müller M, Rakocevic M, Caverzan A, Boller W, Chavarria G. Architectural characteristics and heliotropism may improve spray droplet deposition in the middle and low canopy layers in soybean. Crop Science. 2018;58(5):2029-41. https://doi.org/ 10.2135/cropsci2017.11.0653

30. Tancredi FD, Sediyama T, Reis MS, Cecon PR, Teixeira RDC. Influência da remoção do meristema apical sobre os componentes de produtividade em populações de plantas de soja. Acta Scientiarum Agronomy. 2004;26(1):113-19. https://doi.org/ 10.4025/actasciagron.v26i1.1968

31. Geldner N, Friml J, Stierhof Y-D, Jürgens G, Palme K. Auxin transport inhibitors block PIN1 cycling and vesicle trafficking. Nature [Internet]. 2001;413(6854):425-28. https://doi.org/ $10.1038 / 35096571$
32. Hanna SO, Conley SP, Shaner GE, Santini JB. Fungicide application timing and row spacing effect on soybean canopy penetration and grain yield. Agronomy Journal. 2008;100(5):1488-92. https://doi.org/10.2134/agronj2007.0135

33. Müller M, Rakocevic M, Caverzan A, Chavarria G. Grain yield differences of soybean cultivars due to solar radiation interception. American Journal of Plant Sciences. 2017;08(11):279510. https://doi.org/10.4236/ajps.2017.811189

34. Tariq M, Ahmad Khan T. Screening of Fenugreek (Trigonella foenum-graecum) varieties against root-knot nematode meloidogyne incognita. Journal of Plant Pathology \& Microbiology. 2016;7(2). https://doi.org/10.4172/2157-7471.1000335 